\title{
KMT2A wt Allele
}

National Cancer Institute

\section{Source}

National Cancer Institute. KMT2A wt Allele. NCI Thesaurus. Code C53066.

Human KMT2A wild-type allele is located in the vicinity of 11 q23 and is approximately 89 $\mathrm{kb}$ in length. This allele, which encodes histone-lysine $\mathrm{N}$-methyltransferase 2A protein, is involved in the modulation of transcription by RNA Polymerase II. Several acute leukemias are associated with translocations of the gene. 